\title{
THE SUPREME COURT A CO-ORDINATE BRANCH OF THE UNITED STATES GOVERNMENT
}

The annual meeting of the American Bar Association was held at Washington in October last to commemorate the one hundred and twenty-fifth anniversary of the organization of the Supreme Court of the United States. Addresses were delivered by President Wilson and ex-President Taft. So much attention has been recently directed to the position of this Court in our system of government, and the charge has been so boldly made that the authority claimed by the Court to declare acts of Congress or of the State legislatures to be in violation of the Constitution of the United States and therefore void, is a usurpation, that it is opportune to call attention to American history.

However widely the disputants differ, they all substantially agree on one point, that the government of the United States was a new system and differed in many important particulars from any of the confederations that had preceded it. It was formed by a convention in which each of the thirteen colonies was represented. Each of these colonies declared its adhesion to the new constitution and the government formed thereby went into operation in the year I789. But even during the administration of Washington disputes arose as to the extent of the powers conferred by the constitution upon various departments ${ }^{-}$ of the government. The tenth amendment, adopted during that administration, declared positively what the advocates of the constitution had maintained during the preliminary debates, that "the powers not delegated to the United States by the Constitution nor prohibited by it to the States are reserved to the States respectively or to the People." But in case of a dispute, who should decide as to the extent of these powers? That was a vital question. On this point three theories were held, which until the last decade may fairly be said to exhaust the category.

The first was that each State must decide for itself. The second that each department of the Government should decide for itself. The third was that the Supreme Court was the final arbiter and that all questions involving the construction and effect to be given to the constitution of the United States must finally be decided by that tribunal. 
Of the first of these theories John C. Calhoun was the ablest and most brilliant advocate. He maintained that the United States were a confederation of States, each sovereign. In all cases of a confederation or league, he said, there being no common arbiter superior to the component members, each member must judge for itself of its own rights under the terms of the league, of the infraction of those rights, and of the mode and measure of redress. Each State, therefore, must decide for itself as to its rights, and punish their violation. The second premise of this argument must be admitted; but the first we deny. Our fathers established in I789 a united government,not a confederation.

The colonies were at first independent one of another. They declared war upon their Indian neighbors and made peace with them, issued Colonial currency, and, now and then, when danger made it necessary, entered into treaties with each other, which bound each member to furnish so many men and so much money for the common defense. When the danger ceased, they separated. Alarmed by the Stamp Act, each colony, acting through its Assembly, sent delegates to a Congress. Each delegation represented its own State, and each State voted as a unit. They drafted addresses and made recommendations to the several States, but here their power ended. When the news came from Lexington and Bunker Hill, by independent colonial action troops went to Boston, to New York, to Philadelphia-State, not Continental troops. Dissensions broke out, and the necessity of some bond of union became apparent. Congress proposed to the States articles of confederation, which, among other things, provided, "Each State retains its sovereignty, freedom and independence, and the said States hereby severally enter into a firm league of friendship with each other." These articles were ratified by each Legislature, and not considered binding on a State until so ratified. They were to be amended by the consent of the State Legislatures.

These articles gave Congress power to declare war, make peace, and enter into treaties, but not to levy taxes or imposts; and it could not act on individuals, nor compel obedience to its orders. It recommended the States to raise troops, and the States did, or did not, comply, just as they pleased. Their refusal or delay greatly retarded the success of the war; and when the pressure of immediate danger was removed, and peace concluded, the evil became unbearable. The States enacted hos- 
tile tariffs, refused to be bound by the treaties and laws made by Congress, refused to raise money for the support of the general government, or for the payment of interest on the national debt. Necessity compelled the calling of a convention, and this formed our Constitution. It was ratified by Conventions in each State, chosen by the people of that State, and not by the Legislatures. Its opponents assailed it because it formed, not a league, not a confederacy, but a consolidated government. And its friends, learned, acute-the ink scarcely dry on their signatures to the Constitution-what did they do? Admitted the charge, and justified themselves and their handiwork by asserting that a consolidated government was necessary. Let us quote from the debates in the Virginia Convention:

Patrick Henry said in his speech against the Constitution, June 4, I788:

"I would make this inquiry of those worthy characters of the late federal convention: I am sure they were fully impressed with the necessity of forming a great consolidated government, and the danger of such a government is, to my mind, very striking. I have the highest veneration for those gentlemen, but, Sir, give me leave to demand, what right had they to say, 'We, the People'? My political curiosity, exclusive of my anxious solicitude for the public welfare, leads me to ask, who authorized them to speak the language of, 'We, the People', instead of We, the States? States are the characteristics and soul of a confederation. If the States be not the agents of this compact it must be one great consolidated national government of the people of all the States."

On the 6th of June, Edmund Randolph replied:

"My intention is to satisfy the gentlemen of this committee that a national government is absolutely indispensable, and that a confederacy is not eligible in our present situation. The introductory step to this will be to endeavor to convince the House of the necessity of the Union, and that the present confederacy is actually inadequate and unamendable."

In Mr. Madison's speech in favor of the Constitution he said:

"The distinction between the existing and proposed government is very material. The existing system has been derived from the dependent, derivative authority of 
the Legislatures of the States, whereas this is derived from the superior power of the people." And again: "A government that relies on thirteen independent sovereignties for the means of its existence, is a solecism in theory, and a mere nullity in practice."

The Constitution itself begins with the declaration:

"We, the People of the United States, in order to form a more perfect union, $* * *$ do ordain and establish this Constitution for the United States of America."

Under it the General Government acts directly upon individuals in all cases in which it has power to act at all. This is the essential distinction between a confederacy and a government. The former can only recommend its component States to act; the latter compels its citizens to obey. The Constitution authorizes the General Government to make war and peace, coin money, lay taxes and duties, regulate commerce, define and punish crimes against it. All these the States are prohibited from doing.

We have, then, a Union, not a Confederacy; a Government, not a League. As well might a county refuse to be bound by any but its own construction of a law of the State, as a State set up to judge for itself of the constitutionality of a law of the United States. If one State has the right, all have it. If the question be one affecting their interests diversely, they will decide differently; and who will then decide between them? There can be no arbiter but the sword, revolution or civil war. Well did Mr. Webster say that "if there be no power to settle such questions independent of either of the States, the Union is a rope of sand."

The conclusion of Union men down to the Civil War was that the Central Government had the right to decide as to the extent of its powers and this conclusion was permanently ratified by that War. But the question still remained, In which department of the Government is the authority vested? The theory

\footnotetext{
${ }^{1}$ See 3 Webster's Works, (Little \& Brown ed. in 6 Vols.) 484, for a full collection of the ordinances adopting the Constitution. And see the Speech of James Wilson in the Pennsylvania Convention, November 26, I787; and of Alexander Hamilton, in the New York Convention, June 20, I788. See also Steamboat Company v. Livingston, 3 Cowen, 750, 753 , et seq.
} 
that each department must decide for itself originated early in the last Century. Jackson gave it the authority of his great name, and his faithful supporter in the Senate, Thomas H. Benton, maintained that the Supreme Court had not jurisdiction to decide political questions. This theory is not supported by any provision of the Constitution. Its advocates aver that our liberties are in danger if the Supreme Court has the right to decide constitutional questions. Why we may not rely on it as safely as on the President or Congress we are not told. The principal object of having an arbiter of constitutional questions is to secure uniformity of decision. The theory we are examining does not pretend that a President or Congress is bound by the decision of its predecessors, in fact it asserts the contrary. Each must judge for himself or itself. And they will disagree, and have disagreed. Hence we would be driven to the absurdity of maintaining that what the Government has power to do under one administration it cannot do under another, although the Constitution remains the same. In Washington's administration the Government had power to establish a Bank; in Jackson's it had not. Madison could provide for internal improvements; Van Buren could not. A tariff for protection is constitutional under Adams; unconstitutional under Polk. Admirable certainty of the law! Treason under one administration is praiseworthy opposition to an unconstitutional law under another.

This theory is, however, true to a certain extent. In the first instance each department of the government must of course decide as to its own powers. It does so of necessity in exercising them. And that decision is valid until a case involving it comes before the Supreme Court; and until then, no one pretends that that Court has jurisdiction to decide anything.

The origin of the theory is obvious. The ultimate right of private judgment underlies our whole government. The man . who realizes this says to himself; I am sworn to support the Constitution. My judgment is thus and so. I must carry out my own judgment in the matter. And he says it the more peremptorily if conscience intervene. Then he becomes stubborn. "Men will wrangle for religion," says Lacon, "fight for it; die for it; anything but live for it." But we should remember that liberty is worse than useless unless directed and restrained by law. The right of private judgment, like the freedom of the press, needs regulation. In truth there can be no liberty without obedience to law. 
Nor do we say anything against the right of revolution. Like war, it can be justified only in a case of extreme danger or extreme oppression. But these rights of revolution and conscientious resistance to unrighteous laws do not exist under the law, but in opposition to it. We are now, however, discussing rights which exist under the Constitution and by virtue thereof. And under the Constitution, and in opposition to both the theories we have referred to, we assert that the proper and only arbiter of all constitutional questions is the Supreme Court of the United States, and that from its decision on a case before it there can be no appeal; that by such a decision every officer of the General, State, and Territorial Governments, and every citizen, is bound.

And, first, what does the Constitution itself say? The Sixth Article provides:

"This Constitution, and the laws of the United States which shall be passed in purstuance thereof, and all treaties made, or which shall be made, under the authority of the United States, shall be the supreme law of the land; and the judges in every State shall be bound thereby, anything in the constitution or laws of any State to the contrary notwithstanding."

The Third Article provides:

"Section I. The judicial power of the United States shall be vested in one Supreme Court and in such inferior courts as the Congress may from time to time ordain or establish.

"Section 2. The judicial power shall extend to all cases in law and equity arising under the Constitution, the laws of the United States and treaties made, or which shall be made, under their authority; to all cases of admiralty and maritime jurisdiction; to controversies between two or more States; between a State and citizens of another State; between citizens of the same State claiming lands under grants of different States; and between a State or the citizens thereof and foreign States, citizens, or subjects."

Can words be clearer? The Constitution and laws are supreme. Nothing, then, can be higher. The judicial power extends to all cases arising under them, and to all controversies to which the United States or any State is a party. In such 
cases the Supreme Court has either original or appellate jurisdiction, says the Constitution. Jurisdiction of what? Of the persons only? No, but of the cases also. Of them as a nullity, as a form, sounding but empty? No, but a substantial, efficient jurisdiction, to hear and to decide.

Thus the Supreme Court is made by the Constitution a co-ordinate branch of the United States Government.

The Confederacy even provided a mode of deciding controversies between the States. It would be strange if the Constitution, in all other respects a stronger and more perfect government, should in this particular have fallen short of it. So essential was such a provision deemed that the clauses in the Constitution which we have quoted excited little criticism. They were fully discussed in Convention and deliberately adopted. ${ }^{2}$ They were acquiesced in by the good sense of the country. We do not find that in the conventions of either New York or Massachusetts a single word was said on the subject now under discussion. But in the Federalist the whole Constitution was examined section by section; and the article relating to the Judiciary was in its turn discussed by Alexander Hamilton, who "was born to be great. Whoever was second, Hamilton was first." In this exposition Madison and Jay concurred, so that in the following passages from that work we have the unanimous opinion of these three men, to whom the country has ever looked as high authority in constitutional questions.

"If it be said that the legislative body are themselves the constitutional judges of their own powers, and that the construction they put upon them is conclusive upon the other departments, it may be answered that this cannot be the natural presumption where it is not to be collected from any particular provisions in the Constitution.

\footnotetext{
'James Madison's letter of October 24, I787, to Thomas Jefferson, enclosing copy of constitution, 5 Madison's Works, 22-23, 26-8; 3 Farrand's Records of the Federal Convention, I33-I35; Madison's Speech on Amendments to Constitution, June 8, I789, 5 Madison's Works, 380-I, 385; Madison's letter of December, I831, to N. P. Trist, 3 Farrand, 516; Madison's letter of October 2I, I833, to W. C. Rives, quoting Jefferson's view, 3 Farrand, 522-4; Thomas Jefferson, 5 Jefferson's Works (Ford ed.), 80-I ; 4 Jefferson's Works, 476-7; 5 Jefferson's Works, 5, 45, 47, 76, 77; Alexander Hamilton, The Federalist, No. 78; 9 Hamilton's Works, Lodge's ed., 484-6.
} 
It is not otherwise to be supposed that the Constitution could intend to enable the representatives of the people to substitute their will for that of their constituents. It is far more rational to suppose that the courts were designed to be an intermediate body between the people and the legislature, in order, among other things, to keep the latter within the limits assigned to their authority."

And, quoting Montesquieu, he says: "There is no liberty if the power of judging be not separated from the legislative and executive powers."

It is obvious, from a careful perusal of Elliott's Debates as well as from the Federalist, that the delegates to the several Conventions, and the people generally had studied the history of other nations. Constant appeal is made to this.

Long before 1789 other nations had tried forms of government in which the will of the public officials was supreme and in which the individual had no protection from arbitrary power. By the law of the Roman Empire the will of the Prince was paramount. He had the right by special decree to interpret statutes in reference to cases pending in the courts.

Sic volo, sic jubeo, stet pro ratione voluntas.

The result was tyranny, not freedom.

The Legislative Assembly in France in the days of the Directory had unlimited powers. They were constantly depriving citizens of life, liberty and property without due process of law. The result was justly called the Reign of Terror, and it resulted in national ruin and disgrace. At last Napoleon got into the saddle and at least gave the people security and order. All experience shows that the honest, hard-working people who are the real life and strength of a nation will not long submit to be plundered or oppressed by public officers even though these were selected by a temporary majority of voters. The real majority will have security and order at any cost. The American method embodied in the American Constitution maintains security and preserves order, and protects the life, liberty and property of the individual from unlawful restraint or interference.

This American method of limiting the powers of Executive and Legislative, and entrusting to the Federal Courts the right

"Federalist, No. 78, p. 357, Hallowell ed. 1857.

Ibid., p. 356. 
to decide upon the meaning of the language used in conferring those powers has been in full force ever since the government went into operation in 1789 .

The Federal Circuit Courts, in I79I and again in I795, held that it was not only the right but the duty of the Court to decide that an act of the legislature in violation of the Constitution was void. ${ }^{5}$ How otherwise could the provision be enforced that the Constitution was the Supreme Law? If a law is supreme, it must control. The only way to make its control effective is to enforce it. This enforcement is enforcing the authority that the people, in adopting the Constitution, gave to the Court.

These decisions were in 1803 followed by the Supreme Court in Marbury v. Madison. ${ }^{6}$ In that famous case Chief Justice Marshall, delivering the opinion of the Court, stated (pp. I76-7) with his customary clearness the reasons which led the people to confer this great power upon the courts:

"That the people have an original right to establish, for their future government, such principles as, in their opinion, shall most conduce to their own happiness, is the basis on which the whole American fabric has been erected.

"This original and supreme will organizes the government and assigns to different departments their respective powers. It may either stop here, or establish certain limits not to be transcended by those departments.

"The government of the United States is of the latter description. The powers of the legislature are defined and limited; and that those limits may not be mistaken, or forgotten, the Constitution is written. To what purpose are powers limited, and to what purpose is that limitation committed to writing, if these limits may, at any time, be passed by those intended to be restrained? The distinction between a government with limited and unlimited powers is abolished if those limits do not confine the persons on whom they are imposed, and if acts prohibited and acts allowed are of equal obligation. It is a proposition too plain to be contested, that the Constitution controls any legislative act repugnant to it; or, that the legislature may alter the Constitution by any ordinary act.

"Between these alternatives there is no middle ground. The Constitution is either a superior paramount law

'Van Horne v. Dorrance, 2 Dallas 304.

'I Cranch I37. 
unchangeable by ordinary means, or it is on a level with ordinary legislative acts, and, like other acts, is alterable when the legislature shall please to alter it."

The famous debate in I833 between Webster and Calhoun upon the right of secession turned upon this very point. Calhoun argued that the Constitution was a compact between sovereign States, that there was no common arbiter to decide disputed questions and that each State must therefore decide for itself. Webster argued:

"That the Constitution of the United States... is a government proper, founded on the adoption of the people . . . That there is a supreme law, consisting of the Constitution of the United States, acts of Congress passed in pursuance of it, and treaties, ... . and in cases capable of assuming, and actually assuming the character of a suit, the Supreme Court of the United States is the final interpreter."

It cost this nation thousands of lives and billions of money to establish and enforce this proposition of Daniel Webster.

Perhaps in our time no one has stated this proposition more clearly than President Wilson.?

"Our courts are the balance wheel of our whole Constitutional system; and ours is the only constitutional system so balanced and controlled. Other constitutional systems lack complete poise and certainty of operation because they lack the support and interpretation of authoritative, indisputable courts of law."8

In pursuance of the authority thus conferred by the Constitution, the Supreme Court rendered a series of decisions which really made us a nation. These declared that certain acts of local legislatures were void, and that the supreme law of the United States must control.

In $M c$ Cullough v. Maryland, ${ }^{9}$ the Court held that the Federal Government could not be controlled in the exercise of its functions by the taxing power of the State. It also held the charter

'American Constitutional Government, p. I42.

${ }^{-}$This was written before the Courts of Canada and the Judicial Committee of the British Privy Council had begun to follow our example and pass upon the validity of acts of Canadian Legislatures. Under the Home Rule Act, passed this year, Acts of the Irish Parliament will be subject to the authority of the Courts.

${ }_{4}$ Wheat. 316 (I8rg). 
of the United States Bank to be a constitutional exercise of the power of Congress.

In Gibbons v. Ogden, ${ }^{10}$ it held that commerce between the States could not be controlled by an act of the State Legislature.

In the Bank of Augusta $v$. Earle, ${ }^{11}$ it held that a corporation incorporated under the laws of one State had a right to do business in another.

In the Passenger Tax Cases, ${ }^{12}$ the Supreme Court held that State statutes undertaking to regulate and control immigration into the United States were in violation of the Federal Constitution and that whole subject was a part of foreign commerce which was under the exclusive jurisdiction of the Congress.

In every one of these cases the State Court had decided in favor of the validity of the obnoxious State statute.

It is not too much to say that if these four leading cases had been decided otherwise the United States government would not have been worth preserving, and would have gone to pieces at the first serious assault. A nation whose agencies can be taxed out of existence by a part of the nation, which has no power to provide instrumentalities for interstate and international commerce, whose citizens have no right to trade or do business outside of the limits of their own local jurisdiction, and whose foreign commerce is subject to the control of each particular part, is no nation at all. The bond of such a country would indeed be a rope of sand. .

It was then essential to our national existence that these several statutes which local legislatures had adopted should be annulled by some superior authority and that the rights which they assailed should in some way be vindicated.

There are only two ways in which such rights can be secured. One is peaceable, by an appeal to the courts; the other is forcible, by an appeal to arms. When the subject is seriously considered, it will appear that restrictions upon the power of the courts to enforce peaceably the guaranties of the Constitution will end inevitably in the reign of force. In the kingdom of force, justice is silent and the strongest prevails.

Just now it is fashionable to criticise the action of courts in setting aside legislative statutes, and to claim that legislatures

\footnotetext{
${ }^{10} 9$ Wheat. I (I824).

${ }^{11}$ I3 Pet. 519 (1839).

${ }^{12} 7$ How. 283,412 .
} 
should be exempt from judicial control. But there have been many instances in the history of this country when legislatures have been partisan, oppressive and corrupt. Let us mention a few.

In the early days of the Republic all franchises were granted by special act. When the Federalists controlled the New York Legislature they refused to grant a banking franchise to their political opponents. The bank of the Manhattan Company is a perpetual reminder that Burr was obliged to obtain a banking franchise for his political supporters under cover of a franchise to supply the city of New York with water.

Similar abuses existed in all the States. Constitutional amendments were therefore adopted which prohibited the formation of corporations except under general acts.

Again, in many States, the vast power of taxation has been exerted corruptly or unequally and constitutional amendments to prevent this abuse have been adopted. To what end is this unless the Courts can enforce them?

Just after the Civil War an experiment was tried with legislatures which in fact had absolute power. The legislatures which were established under the Federal government in the states lately in secession were, to all practical purposes, not controlled by the courts, for the judges appointed in those evil days showed no disposition to limit the power of the local legislatures. Indeed federal officials were expressly instructed by the War Department to disregard orders made by the local courts. The result was a reign of corruption and oppression that proved intolerable. In I 877 by general consent the Federal troops were withdrawn from the Southern States and the white people of those states were permitted to manage their affairs in their own way. They went back to the old American principle of legislatures with powers limited by written constitutions, and with courts able and willing to enforce such limitations and vindicate the rights of the people as against legislative excess. Then for the first time prosperity came back to the Southern States. Not only the whites, but the blacks began to accumulate property and the honest, hard-working man for the first time since the war was able to reap the reward of his labors.

One recent instance remains to be mentioned. Within two years the Senate of the United States, acting in conformity to the general public sentiment of the country, set aside-the election of Senator Lorimer by the Legislature of Illinois on the ground 
that it was obtained from the Legislature by the corrupt use of money.

This brief story of legislative corruption and usurpation might be greatly extended. No one who studied it can seriously urge that the power of the courts to deal with unconstitutional legislation should be limited.

To quote again from the Federalist: ${ }^{13}$

"There ought always to be a constitutional method of giving efficacy to constitutional provisions. What, for instance, would avail restrictions on the power of the State legislatures, without some constitutional mode of enforcing the observance of them? The States, by the plan of the convention, are prohibited from doing a variety of things, some of which are incompatible with the interests of the Union, others with the principles of good government. The imposition of duties on imported articles, and the emission of paper money, are specimens of each kind. No man of sense will believe that such prohibitions would be scrupulously regarded without some effectual power in the government to restrain or correct the infractions of them. This power must either be a direct negative on the State laws, or an authority in the Federal courts to overrule such as might be in manifest contravention of the articles of union. There is no third course that I can imagine. The latter appears to

${ }^{13}$ No. 80 , p. 364 . The state courts from the beginning have held that the decisions of the Supreme Court were binding upon them in all cases involving the construction of the United States Constitution. Commonwealth v. Lezeris, 6 Binney (Pa.) 266, 272 (I8I4); Bank of United States $v$. Norton, 3 A. K. Marshall (Ky.) 422 (I82I). At p. 423, speaking of the United States Supreme Court the Court of Appeals of Kentucky said: "Whose exposition of the constitution or statutes of the United States is conclusive on all State Courts throughout the United States," S. P. Steamboat Co. v. Livingston, 3 Cowen (N. Y.) 713, 725, 740,755 (I825). In I827 the Connecticut Supreme Court of Errors overruled its own decision in Smith v. Mead, 3 Conn. 253 (1820), on the authority of the Supreme Court. Hempshead v. Reed, 6 Conn. 480. Sherrill v. Hopkins, I Cowen, I03 (I823), on the same authority overruled Pememan v. Meigs, 9 Johns. 325. Marsh v. Putnam, 3 Gray (Mass.) 43 (I854), overruled on same authority Braquard v. Marshall, 8 Pick. (Mass.) I94 (I829). Many more recent decisions might be cited, but these earlier cases have more historic value. On the other hand, the state courts have frequently refused to follow the decisions of the Supreme Court on questions of commercial law. N. Y. Firemen Ins. Co. v. DeWolf, 2 Cowen (N. Y.) 56, 66, 70 (1823); Rice v. Hart, II8 Mass. 20I (1875). 
have been thought by the convention preferable to the former, and, I presume, will be most agreeable to the States."

Upon this construction of the Constitution the Supreme Court has always acted and its decisions have been enforced. Against the potent opposition of Andrew Jackson it decided the United States Bank constitutional; and under that decision the Bank brought suits in every civilized country, made contracts, issued notes, and men were imprisoned for forging or stealing those notes. When the Civil War came a new National banking system came into being, and has existed in full force and vigor ever since. On the sixteenth of November, I9I4, the Federal Reserve Banks went into operation. That system will be of great public benefit. The authority to create it rests upon the decision in McCullough v. Maryland.

The Supreme Court decided a tariff for protection constitutional, and the revenue of the country was for many years collected under a protective tariff. The same court decided internal improvements constitutional. A powerful party assailed this construction, but it prevailed. Every Congress now passes bills authorizing such improvements, and when Franklin Pierce vetoed such a bill, it was passed over his veto-the first instance of such an occurrence in the history of the country. Massachusetts, Rhode Island, New Jersey, Pennsylvania, Maryland, Virginia, West Virginia, Georgia, Illinois, and Missouri have all appeared in the court-room at Washington before that august tribunal.

Without it what were our boasted Union? A collection of jarring States, quarreling the more bitterly because closely united, and without hope of reconciliation because without a mediator.

There is a fourth theory which has within the last few years found advocates. It is that the People are the final arbiters and that all questions of construction of the constitution must be decided by them. This dogma has received the somewhat vague title of the Recall and Referendum. Put into plain English, what the recall and referendum mean, as applied to constitutional questions, is that the power of a temporary majority over the lives and property of the individual is absolute and uncontrolled. For example, the constitution says that private property shall not be taken for public use without compensation. A piece 
of land belonging to an individual is desired by a temporary majority, and they find it inconvenient to pay its value. A judge decides that the majority has not power to do this. In short, that while the People is sovereign, it is a limited and not an autocratic sovereign. Accordingly he grants an injunction forbidding the officers from taking the land. Thereupon under the operation of the Recall he can be driven from office and a subservient judge elected who will decide in favor of the will of the temporary majority. By the Referendum the question as to whether or not the honest judge has decided right could be submitted to popular vote, and if the temporary majority again voted that he decided wrong, his decision would go for nothing.

When we remember that majorities in a popular government are fluctuating and that the same party that triumphs in one election is often defeated in the next, it will at once appear that to leave questions of individual right to the decision of a temporary majority would simply be to leave the right of the individual in the most vague and uncertain condition. The old maxim is that such a condition is wretched slavery, misera servitus. The despotism of an individual is no more to be feared than the despotism of a temporary majority.

The whole prosperity of the American people has steadily increased since $I 789$, at which time, as has been shown, it was determined that the popular government of the United States should be indeed a government of the People, but that the People had chosen deliberately to impose upon the power of officials temporarily in office certain limits for the protection of the rights of the individual. It is by this union of the sacredness of individual rights with the authority of law within its own sphere, that we obtain security for the individual rights. Without security there can be no prosperity.

In conclusion let us ask: In whose hands could the power of deciding as to the extent of the powers which the People have chosen to confer upon their agents, better be placed than in the Justices of the Supreme Court? Appointed during good behavior, and therefore independent, with fixed salaries, deciding questions of international, constitutional and municipal law, chosen from the first men of the bar of forty-eight states, what method could have been devised which would better secure purity, impartiality, and learning? We dare challenge a comparison with the courts of every, nation in the world. From its first Chief Justice, the Hale of America, John Jay, a learned 
lawyer, a wise statesman, a large-hearted Christian man, whom New York honors as one of her noblest sons, through a long line of illustrious names, Marshall, Story, Bushrod, Washington, Brockholst, Livingston, Chase, Brown, Blatchford,-what court that ever sat can show such a roll? "Si antiquitatem spectes, est vetustissima; si honorem, est honoratissima; si jurisdictionem, est capacissima."

Well might Edward Everett say of it in 1855 : "I do not know what others may think on the subject, but for myself, Sir, I will say that, if all the labors, the sacrifices, and the waste of treasure and blood, from the first landing at Jamestown or Plymouth, were to give us nothing else but the Supreme Court of the United States, this revered tribunal for the settlement of international disputes (for such it may be called), I should say the sacrifice was well made. I have trodden with emotion the threshold of Westminster Hall, and of the Palace of Justice in France; I thought with respect of a long line of illustrious chancellors and judges, surrounded with the insignia of office, clothed in scarlet and ermine, who within these ancient halls have, without fear or favor, administered justice between powerful litigants. But it is with deeper emotions of reverence, it is with something like awe, "that I have entered the Supreme Court at Washington. Not that I have there heard strains of forensic eloquence rarely equalled, never surpassed, from the Wirts, the Pinkneys, and the Websters; but because I have seen there a bright display of the perfection of the moral sublime in human affairs. I have witnessed how, from the dark, low bench, destitute of the emblems of power, from the lips of some grave and venerable magistrate, to whom years and gray hairs could add no new titles to respect (I need write no name under that portrait), the voice of justice and equity has gone forth to the most powerful States of the Union, administering the law between citizens of Independent States, settling dangerous controversies, adjusting disputed boundaries, annulling unconstitutional laws, reversing erroneous decisions, and, with a few mild words of judicial wisdom, disposing of questions a hundredfold more important than those which, without the past year, from the plains of Holstein, have shaken the pillars of Continental Europe, and all but brought a million of men into deadly conflict with each other." ${ }^{314}$

EveretT P. WHEELER.

NEW YoRK CitY.

${ }^{14} 3$ Everett's Speeches, 69. 